\title{
Trophies of War: Representing 'Summer Palace' Loot in Military Museums in the UK
}

Louise Tythacott*

\begin{abstract}
In October 1860, at the culmination of the Second Opium War (1856-60), British and French troops looted and then burnt the imperial buildings in the Yuanmingyuan (known at the time by foreigners as the 'Summer Palace') in the north of Beijing. This widespread destruction of China's most important complex of palaces, and the dispersal of the imperial art collection, is considered one of the most extreme acts of cultural destruction of the nineteenth century. Over a million objects are estimated to have been looted from buildings in the Yuanmingyuan, many of these are now scattered around the world, in private collections and public museums. ${ }^{1}$ This article analyses the display of 'Summer Palace' objects in five military museums in the UK, exploring the meanings constructed around China's imperial artefacts at these particular sites of representation. ${ }^{2}$
\end{abstract}

Key words: Loot, Summer Palace, Military Museums, Opium Wars, China.

\section{Introduction}

Between 7 and 9 October 1860, Anglo-French troops looted buildings in the Yuanmingyuan, known by foreigners as the 'Summer Palace', to the north of Beijing. Ten days later, British soldiers set fire to the entire site, under the direct orders of the British High Commissioner to China, Lord Elgin (1811-1863). The immediate trigger was the torture, in some cases to death, of several dozen prisoners, both British and Indian army troops (Hevia 2003: 47-8; Ringmar 2013:154). It took two days and over 4,800 men to incinerate the numerous buildings (Hevia 2003: 74, 107; Ringmar 2013: 4) - a destruction widely criticised in the West, most notably by the French writer Victor Hugo. ${ }^{3}$

The Yuanmingyuan was the main residence of the Qing imperial family. Initiated in 1709 by the Kangxi Emperor (r.1662-1722), it was developed over the following century by his son and grandson, the Yongzheng (r.1722-35) and Qianlong (r.1736-95) Emperors respectively. Spanning an area of three and a half square kilometres, the Yuanmingyuan included lakes, ponds, streams, canals, gorges, fountains, artificial hills and classical gardens (Ringmar 2013: 37). There were 40 acres of structures and thousands of buildings - palaces, temples, shrines, pagodas, galleries, audience halls, libraries, theatres, model farms, a maze, mosque, aviary and market street - all built to the highest standards demanded by the imperial court (Ringmar 2013: 37-42). The Yuanmingyuan also accommodated one of the finest art collections in the world: according to Thomas, had it survived, 'it would easily rival the Louvre as a global tourist attraction of world heritage' (2008: 13). ${ }^{4}$ Today authorities in Beijing estimate that 1.5 million objects were looted from the Yuanmingyuan, and that many of these are now scattered around the world, in private collections and public museums. This article focuses on objects taken from this palace in 1860, subsequently presented by officers to their regimental messes, and now on display in five military museums in the UK - the Royal Engineers, the Royal Marines, the Wardrobe, the Essex Regiment Museum and The Royal East Kent Regiment at the Beaney House of Art and Knowledge. It is concerned above all with the reformulations of the meanings of China's imperial objects at these specific sites of representation. 


\section{Military museums and 'trophies of war'}

There are around 136 military museums in the $\mathrm{UK},{ }^{5}$ one of the most numerous museum types, but one which has received relatively scant attention in the museological literature. The majority of these museums, as Jones notes, were set up from the 1920s onwards (1996: 153):

(they)...were not formed to present war, but for the specific purpose of instilling and fostering in the regiment the esprit de corps which enables it to fight more effectively. The depiction of the past in regimental museums is required, therefore, to serve a powerful purpose... (1996: 152).

A vital function of these museums, therefore, is to boost the esprit de corps or morale of a particular regiment. In this sense, regimental museums exist to promote a sense of identity, loyalty, shared history, and to inculcate into new recruits feelings of power and success. A recruit's attachment to their regiment - their rationale, if you like, for going to war - is intended to be intensified upon viewing the collections. Through displaying the material culture of past campaigns, exhibitions are used to celebrate victories over the enemy: objects become proof of a regiment's triumph and conquest. Most military museums arrange their displays chronologically, by campaign, in order to clearly promote these messages. As Kirke notes:

Regimental identity absorbs the object's meaning in a museum. Once an object is part of a regiment, it is very hard to break this. If taken away, it will damage the identity of the regiment. The idea that a looted object is not the regiment's is alien to the regiment....They are not loot, they are part of us now...There is a sense of a thread of history via objects... and identity via things (NAM workshop, April 2013).

Objects function here, then, in very specific ways, as part of a wider military apparatus of indoctrination. Military museum displays are examples of instrumentalized learning, where material culture is harnessed to serve a particular purpose.

One of the ways in which objects may be most effectively absorbed into the regiment's history is through re-purposing. Previous uses may be erased and non-Western objects may be modified in order to forcefully assert, or overlay, Western military significance. At the Royal Artillery Museum in Woolwich, for example, are two guns believed to be captured at the Dagu Forts during the Second Opium War, which were melted down and reformed into a Victoria Cross. ${ }^{6}$ What better way to assert complete domination over an enemy in war. ${ }^{7}$ Western inscriptions are also attached to Yuanmingyuan objects, as we will see, in order to underscore their military interpretations.

Yuanmingyuan objects on display in military museums may be conceptualized as trophies of war, a mode of collecting fundamentally characterized by power. As Hill argues, 'trophies... are objects onto which have been projected the social relations of mastery and domination' (2005: 7-8). Yuanmingyuan loot, re-configured as trophies, thus represents a regiment's pride in a victorious campaign. Objects operate as metaphors for feelings of superiority. Classen and Howes write of collected artefacts as 'material signs of victory over their former owners and places of origin' (2006: 208). Hevia refers to objects looted from the Yuanmingyuan as 'emblems of humiliation' (1994: 33). Along with power is a sense of prestige inherent in this mode of collecting (Hill 2005: 7). Indeed one of the characteristics of trophy collections is their triumphant display:

The trophy simultaneously expressed victory, ownership, control and dominion. As such it has three qualities - it presents in material form, however incompletely, sets of practices; it triggers fantasies and memories; and it elicits admiration (Jordanova 1989: 32).

Military museums thus may be conceptualized as places which 'elicit admiration', or as 'shrines to war', where a regiment's most 'sacred' objects are proudly on display. Jones notes how military collections are imbued with symbolism: 'Uniforms, colours, trophies and weapons, placed in displays... are vivid signifiers of those codes and activities which have informed soldiers' lives continuously for several hundred years and which still function in this respect today' (1996: 152). Exhibitions of medals, he argues, reach 'to the heart of the role of the museum as the 
shrine of regimental tradition' (1996: 159). Artefacts associated with Charles George Gordon, in particular, 'were revered almost as the relics of a saint' (1996: 153). In a workshop on military collecting in 2013, Charles Kirke referred to a Zulu shield, obtained by a soldier who received the Victoria Cross, as 'sacred'. ${ }^{8}$ It is the object's association with the highest military decoration in the West which renders it significant, rather than any previous, indigenous associations. The original meanings of non-Western objects in military museums are thus suppressed - or emphasised only when used to calibrate the heroism of the regiment in defeating the enemy (Jones 1996: 157). The value of imperial Yuanmingyuan loot in these museums, therefore, is its ability to attest to the strength of a regiment in conquering the Chinese.

Yuanmingyuan material on display in military museums is used in general to tell a consistent story - as material proof of British superiority over the Chinese (Hevia 1999: 196). These museums represent the views of the conqueror only, with one voice prominent in displays (that of the museum) and one coherent narrative (success in war). Concepts of multi-vocality or dialogic approaches apparent in other museums are not evident (Henare 2005; HooperGreenhill 2000), and there is little engagement with the post-colonial critiques of collecting practices and debates around the ethics of acquisitions and restitution, which have influenced many other museum displays since the 1990s (Clifford 1997; Peers and Brown 2003, Simpson 1996; Tythacott 2010).

\section{The Royal Engineers Museum: religion and relics ${ }^{9}$}

The largest collection of material from the 'Summer Palace' in a UK military museum is located at the Royal Engineers Museum in Chatham, associated with the most famous 'sapper' of the nineteenth century, General Charles George Gordon (1833-1885). Moving to its current location in 1986, the museum exists today to 'preserve and teach the history of the Corps of Royal Engineers' ${ }^{10}$ In the first gallery devoted to 'Early Engineers' are several large cases which exhibit Chinese objects. The introductory text panel is entitled - 'War in China, 1839-1901':

During the $19^{\text {th }}$ century the vast and decaying Chinese empire became an object of European trade rivalries and missionary activities. Britain was involved in three China Wars between 1839 and 1901.

It was the British who first tried to open up China to opium exports and in 1840 required the East India Company to provide troops from India to enforce the trade. A consequence of that was the British acquisition of Hong Kong as a base in 1842 from which business could be conducted....

When Britain tried to extend her trade a further military expedition in conjunction with the French was sent to Beijing in 1860 to force the Chinese government into acceptance. Royal Engineers proved invaluable in it by quickly reducing Chinese fortifications such as the Taku Forts that guarded Beijing.

While Britain is celebrated as the key country to initiate trade, China is characterized here in negative terms. There is no mention of the morality of the trade in drugs or its devastating effect on the Chinese population.

A large case devoted to Summer Palace loot dominates this gallery, the material having been taken by three Royal Engineers - Charles George Gordon, Lieutenant Colonel E $\checkmark$ Thompson and Lieutenant Richard Harrison (1837-1931). The text panel is entitled, 'The Second China War 1859-60 and the Destruction of the Summer Palace':

In 1860 the Chinese Emperor's Summer Palace near Peking (now Beijing) was destroyed by the Anglo-French expeditionary force. The order for the palace to be destroyed was in reaction to the ill treatment of hostages who had been held there. Controversially during this destruction a large number of objects were looted. The Summer Palace which was known as the Yuanmingyuan, or Garden of Perfect Brilliance, had been the favourite summer residence of the imperial court since the early 1700 s and was part of an elaborate complex of gardens... 


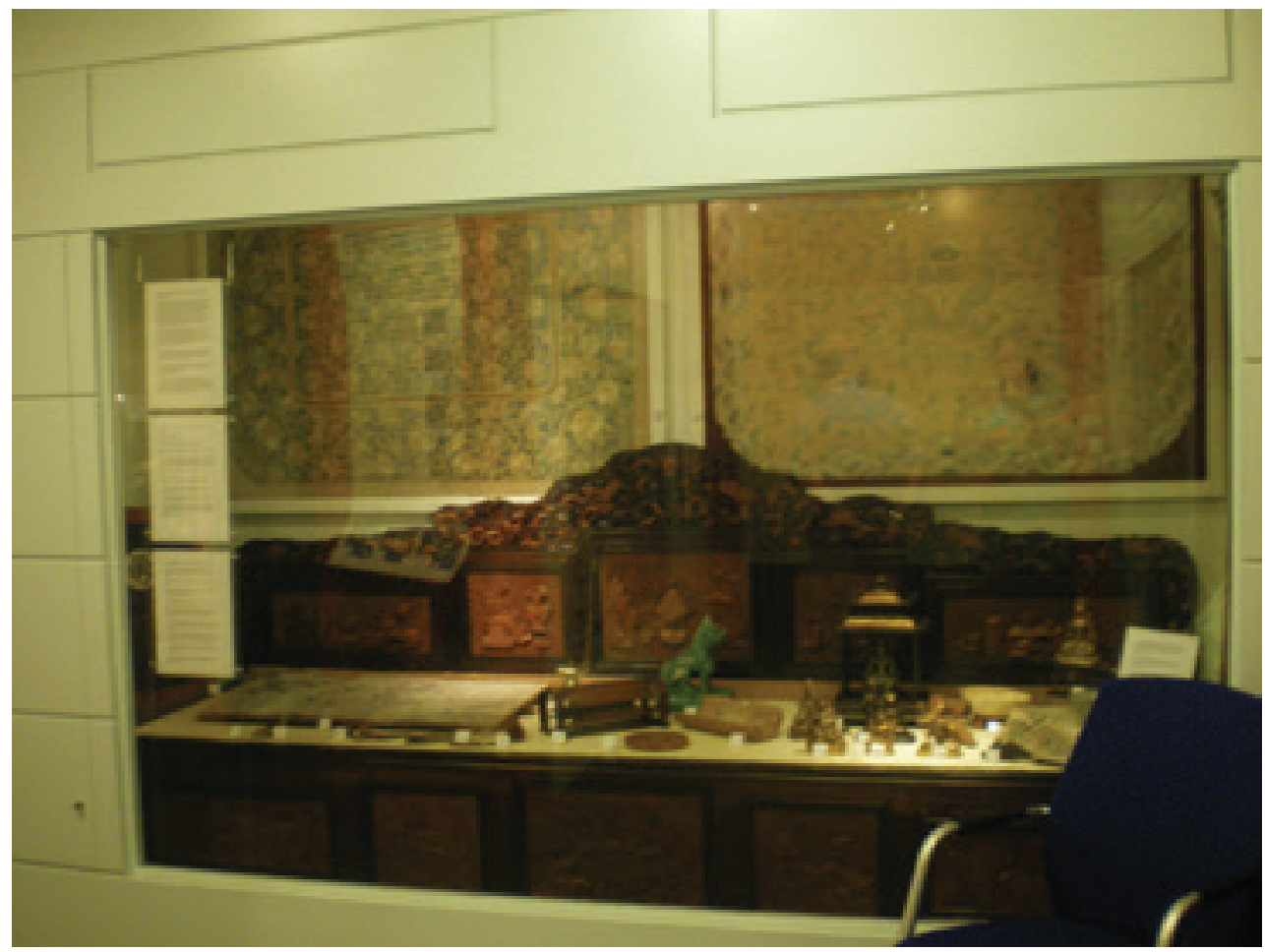

Fig 1. Photograph of case with 'Summer Palace'loot, Royal Engineers Museum. By permission of the Royal Engineers Museum, Library \& Archive.

The destruction of the Yuanmingyuan is justified here on the basis of the 'cruel treatment of hostages', yet the looting is, nevertheless, acknowledged to be 'controversial'. There are inaccuracies in the text, however: the Yuanmingyuan was not a 'summer residence' but the main home of the Chinese imperial family; it was not destroyed by British and French, but by the British alone; and it has recently been disputed whether the hostages were actually kept there (Ringmar 2013).

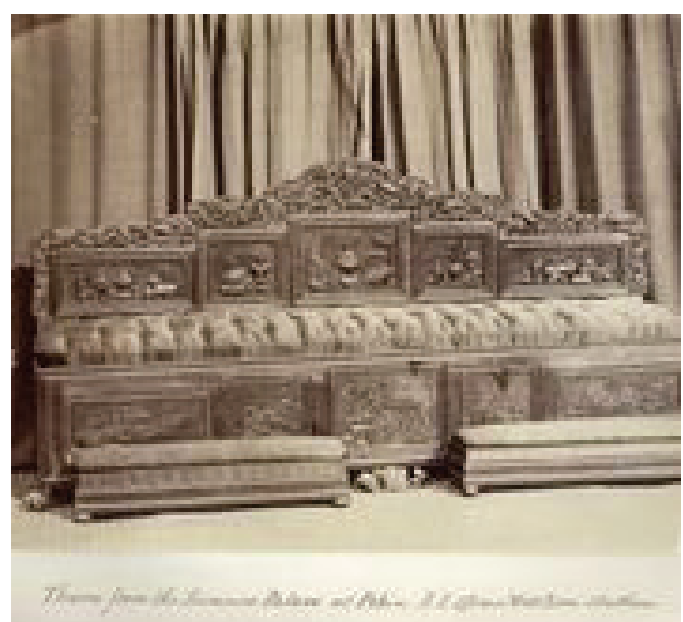

Over 30 objects from China are on display, the largest of which is an imperial throne, acquired by Gordon and donated to his military headquarters (Ringmar 2013: 73). The label for this reads:

Bench made from carved panels... The rear sections are from a square imperial throne, while the front and end panels are of two further designs. The bench was presented to the RE Officers Mess by Gordon in the 1860s, where it remained until loaned to the RE Museum in 1991.

Fig 2. Photograph of the throne c 1860. The throne was described as being removed from the throne room during the sacking. (Royal Engineers Journal, 1909: 49). Copyright Royal Engineers Museum. By permission of the Royal Engineers Museum, Library \& Archive. 
Indeed, James Hevia described it in 1987 in a central alcove of the officers mess, when permission was required to view it in the barracks (1994: $335 \& 341,2003: 329)$. In its original location in a throne room in the Summer Palace ${ }^{11}$, it was reserved for the emperor alone. In the Royal Engineers Museum today it has been transformed into a museological device - a stand used to display the objects.

Behind the throne, attached vertically to the wall, are two large cushion covers, 'from a throne in the Summer Palace' - one, taken by Lieutenant Richard Harrison at the 'sacking of the Palace', embroidered with an imperial five-clawed dragon: $:^{12}$ the other, looted by Gordon, with bats around a lotus flower. ${ }^{13} \mathrm{~A}$ volume of prints, 'Engravings of military campaigns of China's borders', "brought to China by the Jesuit, Guiseppe Castiglione in the eighteenth century" and appropriated from the Yuanmingyuan by Harrison, is placed, opened, on the left hand side of the throne. In the centre are two roof tiles from the Summer Palace: one in the form of a qilin, a mythical beast; the other, yellow glazed, noted as 'reserved for Imperial buildings'. On the right hand side is a lotus shaped bowl 'cut from a single piece of jade', and given by Gordon to a 'brother officer' and 'likely to have been taken by him from the Summer Palace'. ${ }^{14}$ The green roof tile and the jade bowl are also illustrated on a museum leaflet.

A range of small metal Buddhist deity figures, placed on the throne, are also 'believed' to have been taken from the Yuanmingyuan: Amitayus, a deity of long life in a 'Chinese pagoda'15; Cittamani Tara, 'a female deity, fifteenth or sixteenth century'; another Amitayus, 'probably eighteenth century.' ${ }^{16}$ Harrison, in particular, had an interest in Buddhist images: Vaishravana, god of wealth; Tara 'a female deity of long life'; the Protector, 'identified with the Emperor'; Dralha, 'god of war'17. Lady Harrison was able to gift Buddhist-related objects too: miniature coffins; Manchu beads, 'based on a Buddhist rosary'; an incense burning clock; a Buddhist libation cup 'made from a human skull'; a gilt bronze bell dated 1714, 'probably used for ceremonial occasions within the Summer Palace and imperial temples'. ${ }^{18}$ No information is provided to justify this focus on religious things, yet it is evident that such small, portable and high value artefacts would have been attractive and easy for soldiers to remove (Errington 1994). These Buddhist items would clearly have been viewed by the British soldiers with disdain (Wolseley 1862). ${ }^{19}$ Deity figures thus function here, not in an atmosphere of reverence, as they would have been in the original temples, but rather as relics ${ }^{20}$, obtained by heroic men, and as trophies of the perceived superiority of one belief system over another.

\section{The Royal Marines Museum: ${ }^{21}$ debased objects}

The Officers' Mess of the Royal Marines Barracks in Portsmouth, built in 1867-8, was transformed into the Royal Marines Museum in 1975. ${ }^{22}$ The displays, which span three floors of the imposing building, are organised chronologically, with the early beginnings in 1664 to the present. The Chinese objects are exhibited in an area devoted to the 'Opium Wars 1840-1900 and Crimea 1854-1865'. The text panel on 'China and the Opium War' reads:

'China':

By the $18^{\text {th }}$ century China had the oldest and largest empire in the world. The Chinese treated all other states as inferior and considered all Europeans as barbarians. Only a few ports were open to foreign trade and while British traders wanted tea and silk, the Chinese had no need of British goods.

The British were frustrated and the two empires clashed in what became known as the Opium War.

While this text characterizes China as arrogant, in fact, as Ringmar has argued, it was the Europeans who perceived the Chinese as the 'barbarians' in the nineteenth century (2013). Another text panel, 'The Opium War', in fact justifies drug usage:

Opium was a commonly used drug in Victorian England. Doctors prescribed it for a variety of ailments ranging from toothache to hayfever and flu. Children were raised on it as a sedative medicine. The poet Coleridge, the composer Berlioz, 
and the anti-slavery crusader, William Wilberforce, all used the drug.

The trade in opium was enormous and worth millions of pounds. The British Empire had the monopoly on the world's cultivation and export of opium. Although the Chinese had made opium taking illegal, the British encouraged addiction to create a new trade with China. In 1839, the Emperor banned all trade in opium and punished it by death, which the British found intolerable and declared war.

The Royal Navy and Royal Marines were involved in attacks on Chinese towns, forts and strong points during the 3 year war. The result was the defeat of China and the beginning of the end of their empire's power. Britain acquired Hong Kong and became master of the Far East.

Further tensions led to a second war in 1856 with greater Royal Marine involvement and the capture of Peking.

A Buddha statue and a pair of cloisonné vases from the Summer Palace are displayed in the section on the 'Opium Wars and Boxer Rebellion'. The bronze Buddha figure is possibly eighteenth century, seated crossed legged on a lotus throne, its hands held close to the chest in a pose known as dharmachackra mudra. It is flanked by two gu shaped cloisonné vases, probably dating to the late eighteenth century, with flanges on each corner throughout. The label in the display reads: 'Chinese vases and a Buddha captured from the Emperor of China's summer palace, the Yuen Ming Yuen by Lieutenants Walter and Barker of the RMLI Battalion on 8 October 1860 , towards the end of the Second China War.' Hevia (2003: 86) has discussed the significance of objects associated with the Emperor of China, and 'the use of the definite article "the" for those objects where a substantive link was drawn between these things and imperial sovereignty' (1994: 334). The Emperor's name and dates of his reign, however - Xianfeng (r.1850-1861)-are not included in this label, representing him as anonymous and ahistorical.

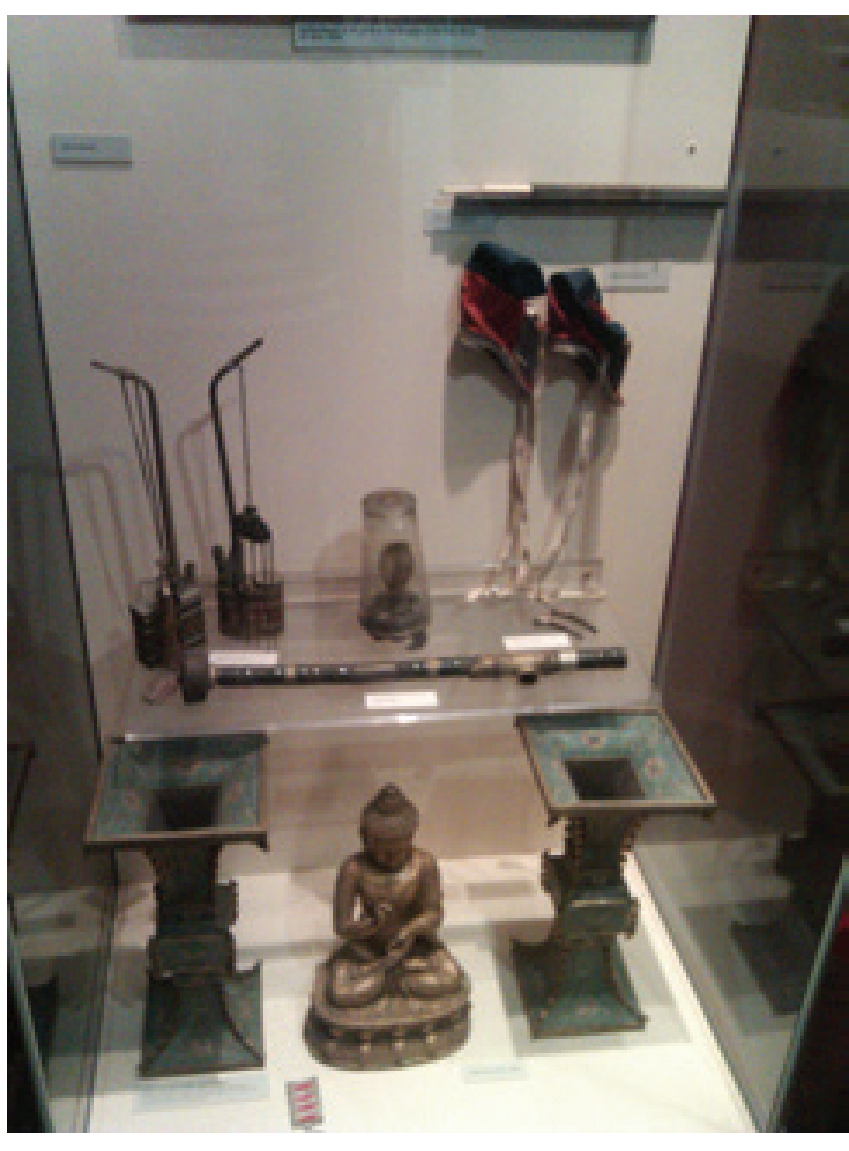

Fig 3. Photograph of Buddha and cloisonné vases, Royal Marines Museum, Portsmouth. The Buddha is possibly eighteenth century, seated crossed legged on a lotus throne, its hands held close to the chest in dharmachackra mudra. Two Gu shaped cloisonné vases, probably late eighteenth century, with flanges on each corner. Taken by author in 2011 at the Royal Marines Museum. 
for the collection (or 'capture') of the objects, their period of manufacture is omitted, portraying China as a timeless culture (Price 1991).

The three imperial objects sit beneath everyday Chinese things taken during later campaigns. On the shelf above them is an opium pipe and finger extensions. Tiny embroidered shoes for bound feet are attached to the wall, just below a knife and chopsticks in a bamboo scabbard. Originally, a pigtail made of human hair was on display, though only the label remains.$^{23}$ Exhibited together, these items produce an image of Chinese culture associated with drugs, exoticism and cruelty - reducing the country to negative stereotypes. The Buddha looks strange placed low down on the base of the case. In terms of Buddhist practices this posturing is inappropriate: Buddhas should always be elevated, with their heads above human heads, not placed close to the floor, which is considered unclean. In front of the Buddha is a China medal - '1857-1860'- a placement which stamps the aura of military trophy on to these three beautifully crafted objects. Their proximity to a war medal signifies their role as artefacts of subjugation. They are debased, literally, through their low position, and the medal reminds us why they are on display in Portsmouth, out-of- place and de-contextualized.

\section{The Wardrobe: an imperial robe and five vases ${ }^{24}$}

The Wardrobe Museum in Salisbury Cathedral Close was originally built in the thirteenth century as a store house for the Bishop's documents and clothes. The regiment acquired the building in 1979, and opened a museum in $1981 .^{25}$ Today the Wardrobe holds the collection relating to the infantry regiments of Berkshire and Wiltshire from 1748. It is arranged in four ground floor rooms and displayed chronologically, from the early beginnings to the present day. In the second gallery can be found a robe and five pieces of porcelain from the Yuanmingyuan, the property of the $99^{\text {th }}$ Regiment of Foot, in a case on 'Crimea and Opium Wars'. Of the text panels inside the case, one of them - 'Oriental legacy'- has the sub-heading, 'From Calcutta to Pekin':

...the British and French forces... plundered the treasures of the Emperor's Summer Palace, which was set in pleasure gardens with panoramic views. The articles removed by the British officers were auctioned for about $£ 30,000$. The proceeds were split, one third to the officers and two thirds to the men...

Another A4 text panel, placed in front of the Chinese ceramics in the case, is devoted to the 'Chinese Dragon Robe, Qing dynasty (1644-1911)'. The first and last paragraph state:

In 1860 , the $99^{\text {th }}$ regiment...took part in an expedition to China and participated in the Second 'Opium War' and the 'sacking of Peking'. The robe was taken from the Imperial Summer Palace by the regiment which was under the command of Captain Henry Ely. The Chinese embroidered silk dragon robe from the Qing dynasty once belonged to the Emperor of China -Tao Kwang. It would have been worn as part of the 'auspicious' or semi-formal attire typically for celebratory occasions...

.... In 1856, the Second Opium War began and ended, with the Chinese being defeated once more. As a result, they were forced to sign the Treaty of Tientsin, and the sale of opium was legalised. The British claimed that the Chinese people had a 'right' to this 'harmless luxury' without regard to its own government. Opium imports increased in unprecedented levels. By the end of the nineteenth century, an estimated quarter of the male population of China was addicted to the enhanced opium.

The robe is clearly perceived to be one of the most important objects in the Wardrobe's collection. Embroidered on yellow silk, a colour reserved for the emperor and key members of the imperial household, it is a longpao, or dragon robe, worn as part of jifu or festive dress, for semi-formal occasions, with five-clawed dragons, stripes at the bottom representing water and Twelve Symbols (Dickinson and Wrigglesworth 2000; 44, 76-96). Eight dragons are visible and a ninth is under the flap which fastens over the right-hand-side. A photograph of the textile, with the five vases, is advertised on the signboard in the grounds outside the building, the 


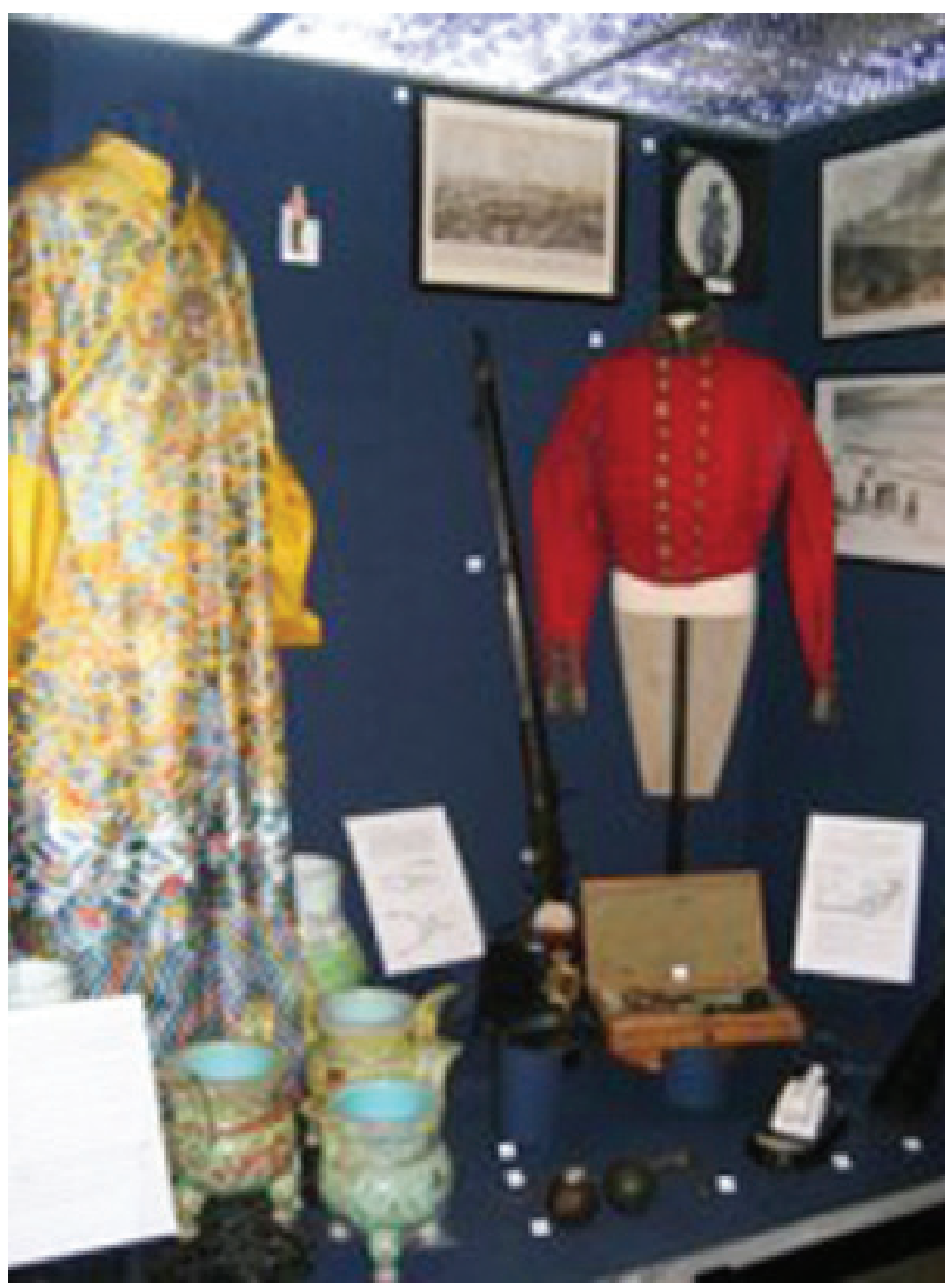

Fig 4. Photograph of robe and vase taken by the 99th Regiment in 1860. The Wardrobe Museum, Salisbury. Taken by author in 2011. By permission of the Trustees of The Rifles Wardrobe and Museum Trust.

caption reads: 'Why do we have a Chinese Emperor's Robe?' This image is also reproduced on the front cover of the main museum leaflet. The Wardrobe Military Museum Textile Trail Catalogue, which was produced in association with the National Association of Decorative \& Fine Arts Societies (NADFAS), however, contests the gender attribution, by arguing that the robe belonged to an 'empress' instead. An A4 page in their catalogue is entirely devoted to its symbolism and design: 'The presence of some of the imperial symbols in this particular grouping together with the colour of the silk and the longevity symbol design makes it likely that the robe would have been made for the empress dowager' (NADFAS). The two conflicting gender interpretations are not evident in the gallery, however, for all references in the museum displays are to the 'emperor'. It is evident that this is not a garment of the highest quality: it is incomplete - lacking cuffs and sleeve extenders - and has an inappropriately high collar. 
According to Hill, it may never have been used, for it is 'seamed incorrectly and finished with a Nehru collar and barrel cuffs', leading her to speculate that Ely took an 'unfinished robe', 'tailored later for display' (2012a: 20).

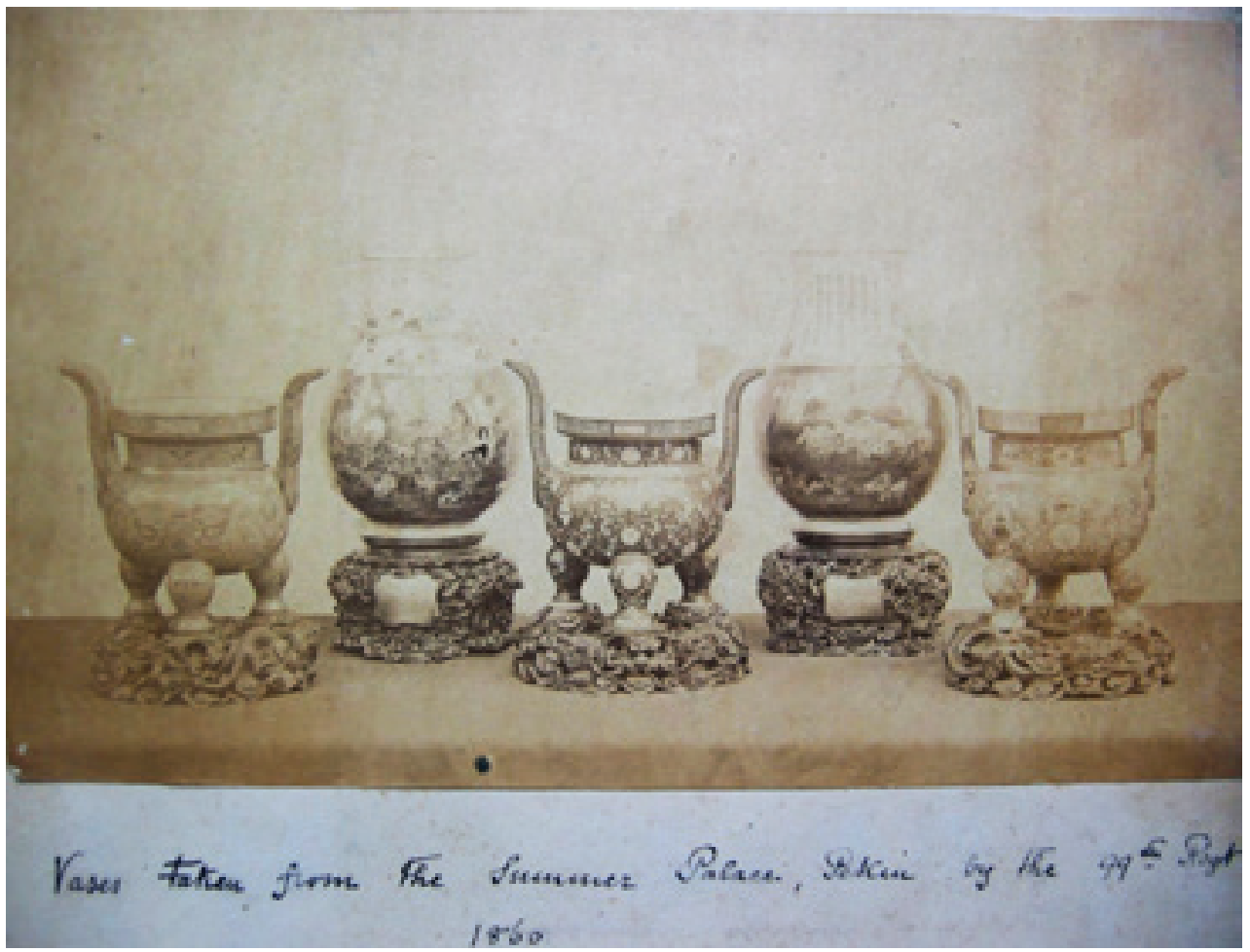

Fig 5. Photograph of five vases taken from the Summer Palace by the 99th Regiment in 1860. Copyright Wardrobe Museum, Salisbury. By permission of the Trustees of The Rifles Wardrobe and Museum Trust.

Five porcelain vases in the case were also taken at the sacking of the Yuanmingyuan - three tripod censers with Qianlong reign marks and two large hu vases with Daoguang (r. 1821-1850) marks (Hill 2012a:18), the latter with inscriptions indicating they were 'reverently offered' to 'His Majesty The Emperor Tao-Kwang by his Chancellor, Chu Lin, in 1830' (5085 \& 5086). Hill posits that the two hu vases, enamelled with the 'One Hundred Horses' theme in the style of the Jesuit Castliglione (1688-1766), may have 'appealed to soldiers due to the Western style of composition' (2012a: 18). ${ }^{26} \mathrm{An}$ A4 translation of the ode on the two hu is typed out in full and placed on the side of the case. The name of the translator - Wm.S. Fredk. Mayers, Secretary of the Legation in Beijing - is included, with location and exact date (Canton 1 June 1861). While the Western details of translation and possession are meticulously recorded and displayed, the circumstances under which the vases became the property of the Officers' Mess are noted as 'uncertain' in the museum's documentation (database entry: 28799). It is remarked upon too that the lids of the three tripod censers went missing when taken from the Yuanmingyuan and all five 'suffered over the following years from the battalion's travels' (Mclntyre 2007: 31).

Hevia talks of the 'theft and the redistribution' of objects from the Summer Palace as a 'process of subversion', made particularly more intense when objects 'could be tied directly to the person of the Qing emperor' (2003: 86). The yellow robe may thus have had a particular aura for Captain Ely and the soldiers of the 99th, perceived as it was to have been worn by the 'untouchable' emperor: two of the vases, as we have seen, also have documentation confirming their imperial connections. These objects thus function as trophies of the victory of the Regiment in conquering, not just the Chinese, but the Chinese ruling elite. 


\section{Essex Regiment Museum: a cloisonné incense burner ${ }^{27}$}

A gallery devoted to the $44^{\text {th }}$ (Essex Regiment) opened in January 2010 at the Chelmsford Museum. ${ }^{28}$ According to the curator, the museum was among the first generation of those to move out from 'behind the wire' into local authority care ${ }^{29}$ Today Chelmsford Museum covers natural history, Roman Chelmsford, and Chelmsford's industrial heritage. Located on the first floor and arranged chronologically, the Essex Regiment Museum tells the story of the

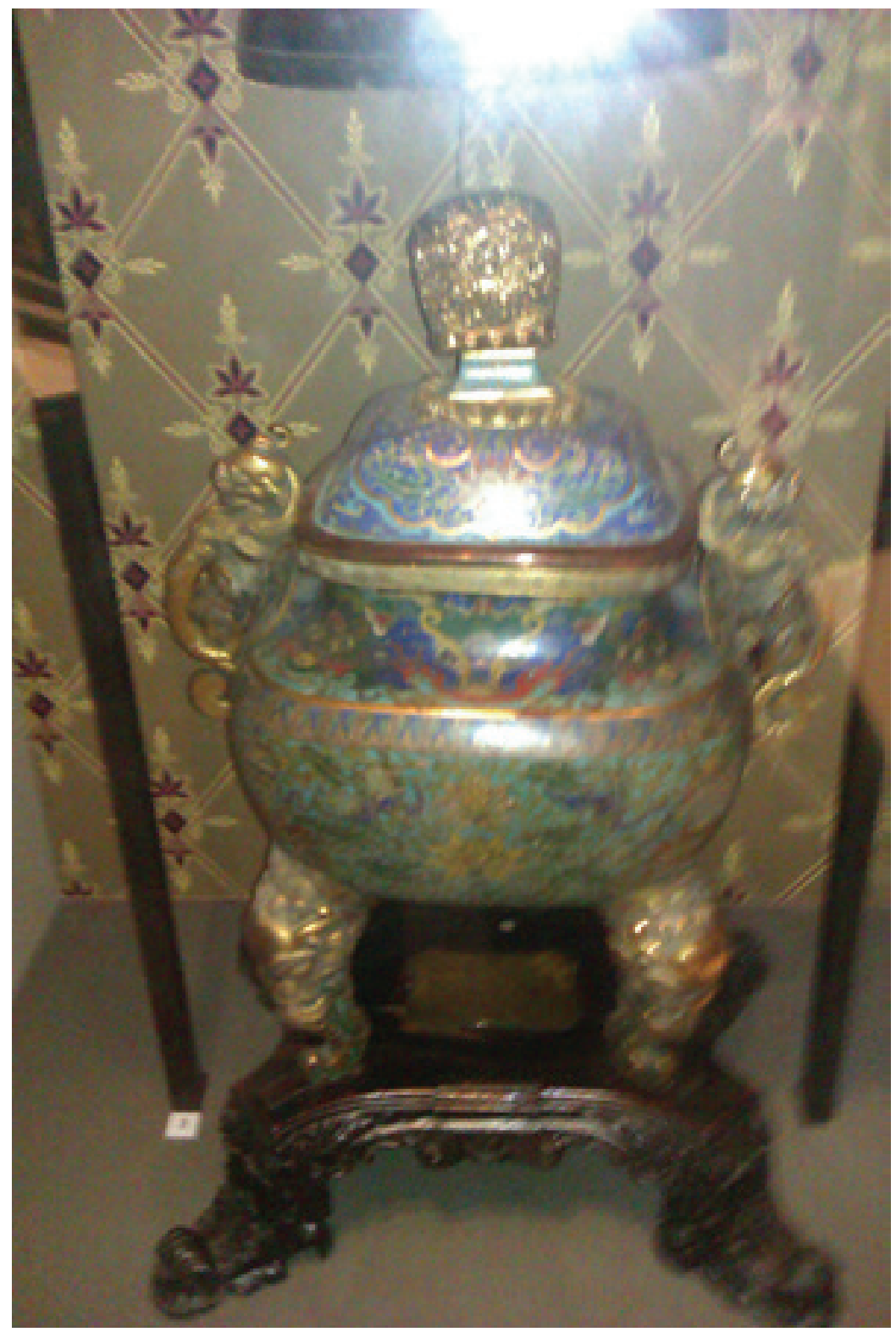

Fig 6. Photograph of cloisonné censer. Probably Jiaqing (r 1796-1820). Gilded cloisonné, with gilded and reticulated knop and lion mask legs. On display in present gallery, Essex Regiment Museum. Taken by author in 2011. 
Regiment from its origins in 1741, through major campaigns. On the far left hand side of the gallery, and hidden from view as you approach, is a case devoted to 'Trophies of War', where the star object - an imposing cloisonné incense burner from the Yuanmingyuan - is proudly on display. A text panel nearby discusses 'Trophies':

Regiments, like school, colleges and families, gather relics. Some are bought, others presented, and many taken in battle as plunder or loot...Valuable and sometimes of religious or ethnic importance, they were placed in the Officers' Mess...From 1873 each Regiment had a Depot where items were left to be seen by guests and shown to recruits to promote Regimental pride... These collections often became Regimental museums.

An extended text devoted to the 'Summer Palace', on laminated sheets in the gallery, reads:

The Yuanmingyuan Palace, built in $18^{\text {th }}$ and early $19^{\text {th }}$ century, was destroyed by English and French forces on $18^{\text {th }}$ October 1860 , in what is condemned as the greatest act of cultural vandalism in modern history... as the palace was explored, 'gold watches and small valuables were whipped up by these gentlemen with amazing velocity, and as speedily disappeared into their capacious pockets'. On Sunday morning, 7 October, orders against looting were withdrawn and English and French soldiers rushed around taking every valuable which they could carry. What could not be carried away was destroyed. Some amused themselves by shooting the chandeliers, other by playing pitch-and-toss against large mirrors, while some armed themselves with clubs and smashed to pieces everything too heavy to be carried, finishing by setting fire to the Emperor's private residence.

\begin{abstract}
.... Lord Elgin ordered that the palaces should be levelled with the ground. The French refused to assist but Elgin was determined. Soon flames appeared above the devoted structures, and long columns of smoke rose to the sky, until the smoke hung like a vast storm-cloud over Peking...
\end{abstract}

Accurate and well-researched, this is the most detailed discussion of the looting of the Yuanmingyuan in any military museum in the UK. The label for the cloisonné reads:

Chinese Cloisonné vase. Looted by British and French troops from the Chinese Emperor's Summer Palace atPeking during the Second China War.

The destruction of the Summer Palace is regarded as one of the greatest acts of cultural vandalism of modern times.

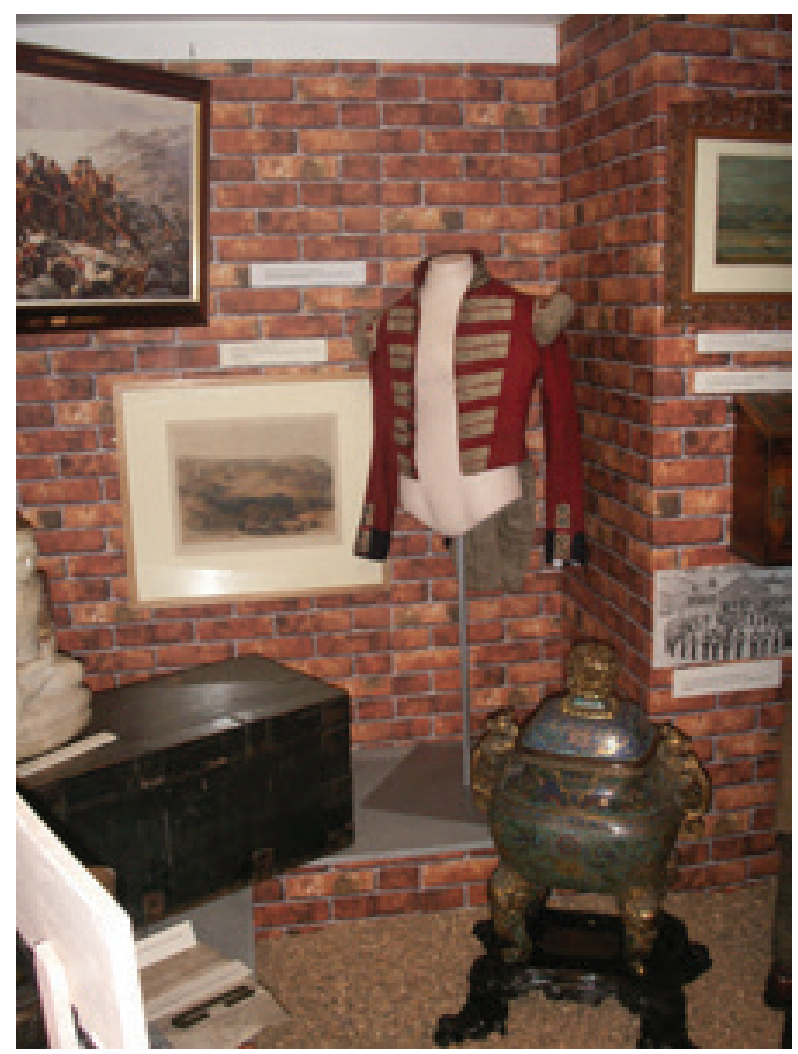

Fig 7. Photograph of cloisonné on display in pre-2010 gallery. Copyright Essex Regiment Museum. 
The cloisonné was acquired by Lieutenant Thomas Orton Howarth of the $44^{\text {th }}$ Foot who was serving with the Chinese Coolie Corps. ${ }^{30}$ It is gilded cloisonné, with a reticulated and gilded knop, lion mask legs, and it most likely dates to the reign of Jiaqing ( $r$ 1796-1820). It sits within a wooden frame, a bell from Sevastopol suspended over it, and a Burmese Buddha placed high on top. A detail of the cloisonné is prominently illustrated in the leaflet devoted to 'Museum Services'. Hook notes this as 'a starred item' 31 : it has been proudly exhibited since it was looted in 1860. In the pre2010 gallery, it was placed on a wooden stand made for the Regiment in India, ${ }^{32}$ a mannequin with an officer's uniform next to it. ${ }^{33}$ In 1955, it was photographed in Warley Barracks, some miles

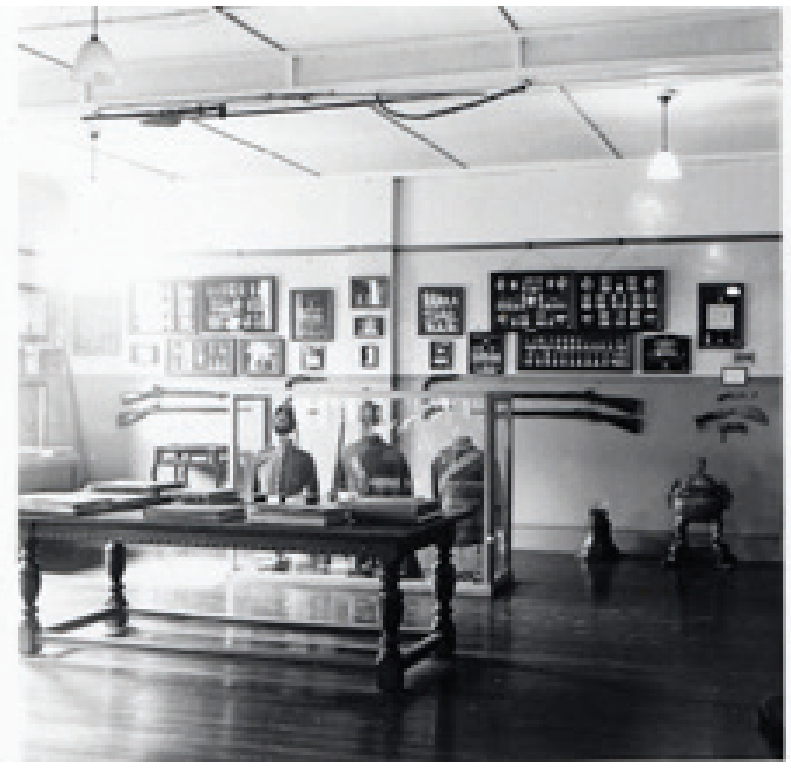

Fig 8. Photograph of cloisonné on display in Warley Barracks in 1955. Copyright Essex Regiment Museum. from Chelmsford. Here it can be seen on the floor surrounded by medals on the walls, weapons and regimental uniforms.$^{34}$ In 1899, the incense burner was also illustrated in a photograph of a ball held at the barracks. Placed on its stand, it is the centrepiece of a table display,

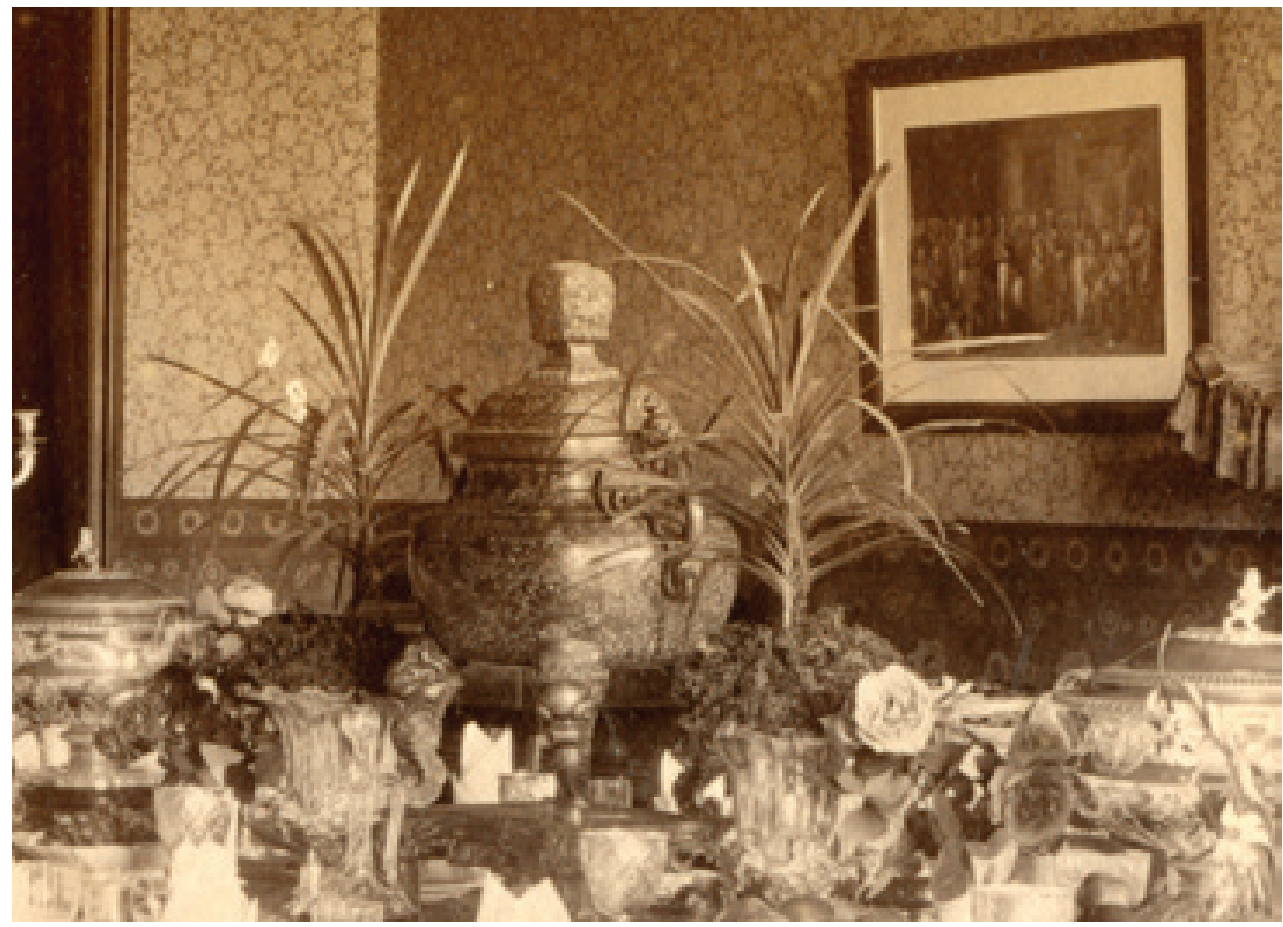

Fig 9. Photograph of cloisonné on display at the Warley Ball in 1899. Copyright Essex Regiment Museum. 


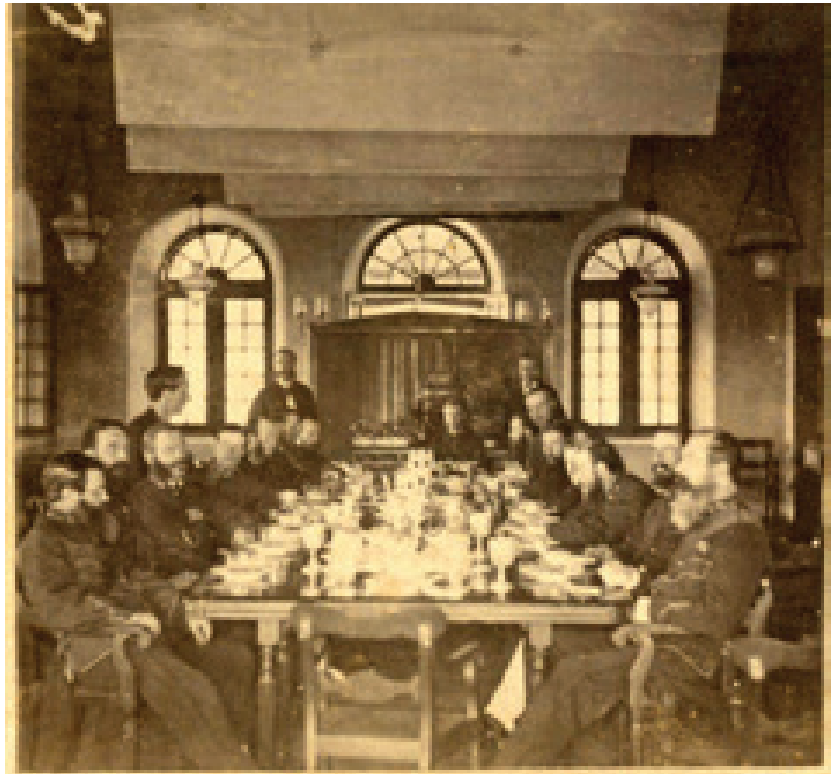

Fig 10. Photograph of cloisonné on display in the Mess Dining Room, Belgaum, in 1864. Copyright Essex Regiment Museum.

flanked by plants, silverware and flowers, and behind, on the wall, is a depiction of officers of the Regiment. Perhaps the most striking trophy image is a photograph in 1864 of the 'Mess Dining Room, Belgaum' in the state of Karnataka, India, only four years after the China campaign. Two rows of soldiers are seated either side of a long dining table, with the cloisonné taking centre stage at the back. The Yuanmingyuan loot would have operated here as a poignant symbol of success in a war these officers would have known only too well.

The cloisonné censer thus has had a rich and well documented past with the $44^{\text {th }}$ Essex Regiment over the last 150 years, but what of its future life? The curator at the time of writing notes, 'I have given consideration to the day when the Chinese ask for restitution of looted treasures. My own recommendation would be to cede ownership and ask for the loan of the item in order that the history of this period can be illustrated in this country at a local level'. ${ }^{35}$ This extraordinarily fine piece of imperial Chinese workmanship may well have a fascinating future existence.

\section{The Buffs: 'Heroes and Villains'36}

A small part of the collection of the Buffs (Royal East Kent Regiment) is housed within a local authority museum - the Beaney House of Art and Knowledge in Canterbury. Objects belonging to the Buffs' collection were loaned by the National Army Museum to the Beaney following the latter's $£ 14$ million refurbishment; the new displays opened in September 2012. As expressed in 2012, the ethos of the Beaney is 'to enable people to explore, learn, participate, and create using the permanent collections, special exhibitions, community engagement programme and educational activities as inspiration' (Guidebook 2012: 2). Moving away from the traditional museological galleries based on nineteenth century classifications, the spaces have been renamed: 'The Front Room', 'The Garden Room', 'Colour and Camouflage', 'People and Places', 'Material and Masters'. The experimental approach is evident throughout, as is an awareness of latest trends in museological display. On the first floor is 'The Study' which includes a large case - a 'Cabinet of Curiosities' - evoking the origins of the collections at the Canterbury Philosophical and Literary Institution, which opened in 1825. Yuanmingyuan objects are displayed in a large case in the gallery devoted to 'Explorers and Collectors'. The Royal East Kent Regiment (originally known as the $3^{\text {rd }}$ Regiment of Foot) is one of the oldest in the British army, with origins dating back to $1572 .{ }^{37}$ The text associated with the Opium Wars reads 'China, 1860':

In 1859 Britain and France wished to impose a trade treaty on China, which would open all of the country to Western merchants and legalise the opium trade. When the Chinese refused to admit a delegation, and fired on the British fleet trying to sail up the Pei Ho River, a Franco-British army, which included the Buffs, was sent to impose the treaty by force. ${ }^{38}$ 


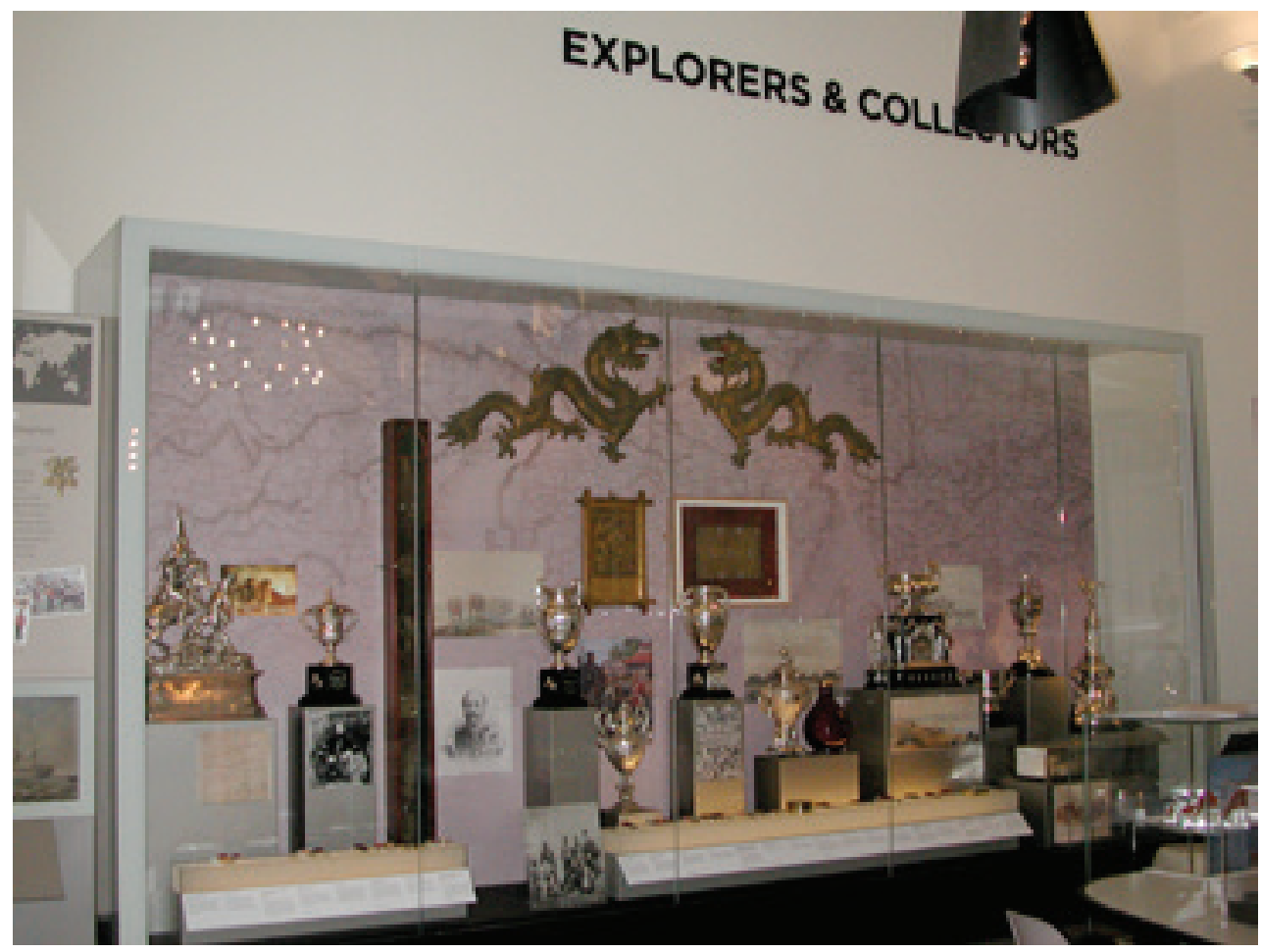

Fig 11. Photograph of 'Explorers \& Collectors' case, the Beaney House of Art and Knowledge. Taken by author in 2012. Reproduced courtesy of the National Army Museum.

While the Buffs were left to garrison the Dagu forts on the northern approach to Beijing, an officer, Colonel Mark Walker, was attached to the General's staff, and travelled to the capital. The gallery label notes, 'Many beautiful items were lost or destroyed, but some were auctioned'. Colonel Walker bought a vase, and possibly a box at the auction in Beijing, both of which are on display in a case on the Royal East Kent Regiment. ${ }^{39}$ The porcelain is a deep red, with a silver rim made by silversmiths Cook and Kelvey in Calcutta as early as 1860 . On the lid is an inscription: ' 1860 , looted at Pekin and presented to the mess of his regt. By Col. Walker V.C.' The brass box is also noted as removed from Beijing in 1860 by Walker, and presented to the mess of his regiment (NAM inventory). An inscription in Arabic on the lid reads, 'Allhamdu Lillah' 'Praise to God'. Around the side of the box is a silver plate with a badly worn inscription identical to that of the vase: 'Looted at Pekin and presented to the mess of the Regt By Bv Lt Col Walker 1st Batt the Buffs'. ${ }^{40}$

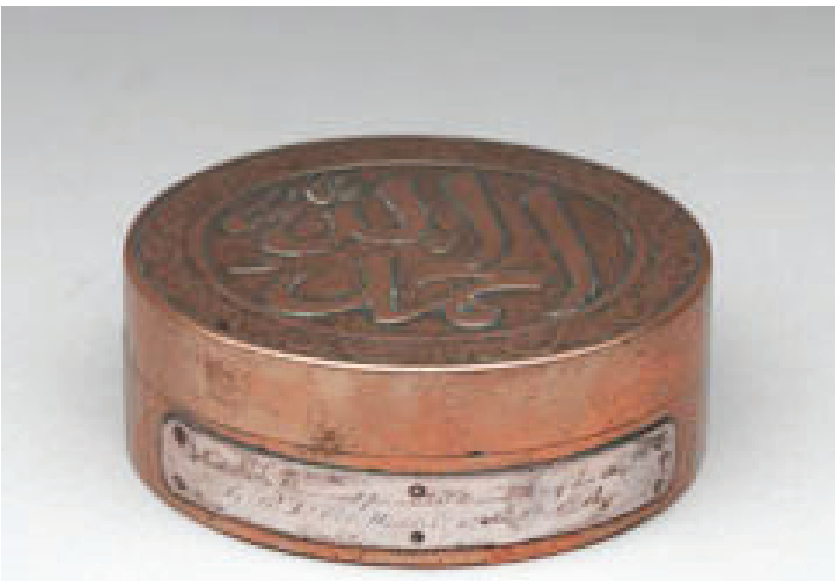

Fig 12. Brass box with inscription. Copyright National Army Museum. Reproduced courtesy of the National Army Museum. 
We see here how the biographies of these objects have been marked and reconfigured through the Western inscriptions indelibly attached to them. During a presentation as part of a workshop on military collecting in 2013 , an image of this box was shown to the audience and a member of the group - with a military background - asked about the inscription. I assumed he meant the prominent Arabic on the lid, but his concern was with the Western text alone. The military thus have very specific interests when interpreting such looted objects. ${ }^{41}$

The case on the Buffs is in a gallery devoted to 'Explorers and Collectors', where Greek and Egyptian archaeological material is displayed alongside objects from Asia, Africa, India and South America, brought back by soldiers, missionaries and diplomats. Interestingly, this new gallery presents a nuanced approach to collecting by discussing collectors as both 'heroes' and 'villains'. ${ }^{42}$

\section{Conclusion: ‘liberated' objects ${ }^{43}$}

In tracing the histories of Summer Palace loot in the West, Hevia has noted how such objects gained new meaning in different sites, which 'embedded them more deeply in alien discourses' (1994: 320) - and perhaps we can argue that the Western military museum is the most 'alien' discourse of all. Over the past few decades the museological literature has discussed the complexity of meanings attached to material culture in different spheres of representation (Ames 1992; Henare 2005; Hooper-Greenhill 2000; Kopytoff 1986; McCarthy 2007; Steiner 1994; Thomas 1991), and this article has demonstrated how Chinese imperial treasures have become absorbed into the ideological frameworks of military museums in very particular ways. We have seen the radical transformations of the significance of these objects in these sites of museological representation, as they are clearly intended to be read in terms of narratives of conquest and power. Some displays of Yuanmingyuan loot remain traditional in interpretation, with objects conceptualized as 'trophies of war', used to inform and induct regimental recruits. Text panels promote the righteousness of the British attacking China and the looting of the imperial collections. Indeed, one curator I spoke to even referred to 'Summer Palace' objects as 'liberated' by the Regiment, rather than 'looted' from China. More recent redisplays, however, problematize these acquisitions by presenting objects in exhibitions which are more reflexive and critical of the circumstances of encounter. In doing so, they touch upon important - and timely - issues regarding the relationships between China and Britain in the mid-late nineteenth century.

Received: 15 April 2014

Finally accepted 30 June 2015

\section{Acknowledgements}

I would like to thank the following for their help with the research: Richard Kirkby, Polly Marshall; Ken Tythacott; Amy Adams and James Scott (Royal Engineers); Anna Lebbell (Royal Marines); Ian Hook (Essex Regiment Museum); Alastair Massie, Emma Lefley and Julian Farrance (National Army Museum); Craig Bowen (The Beaney, House of Art and Knowledge).

\section{Notes}

1 According to the Director of the Yuanmingyuan, Chen Mingjie. Cited in Macartney, 2009.

2 This paper is part of a wider project documenting the representation of Yuanmingyuan material. I have benefited greatly from participating in a series of workshops in 2013, 'Hidden in plain sight: non-European collections in military culture', funded by the Royal Society of Edinburgh and National Army Museum, and organised by Henrietta Lidchi and Stuart Allen. My thanks to all those who participated in this event. I am also grateful to the participants at the conference, Yuanmingyuan in Britain and France, held at the University of Manchester in July 2013.

3 In a letter to Captain William Butler of 1861. See 'The Sack of the Summer Palace', UNESCO Courier (November 1985): 15, for the English translation. 
4 See Hevia (1994, 1999 and 2003) for a critical appraisal of the reformulation of 'Summer Palace' objects as 'loot'; Ringmar (2013) for a detailed analysis of the destruction of the palaces; Thomas (2008) for a discussion of the relations between China and the French in relation to the looting of the Yuanmingyuan; and Hill (2012) for an account of military collecting during the Opium Wars. For general discussions of the architecture of the Yuanmingyuan, see Wong (2001) and Chiu (2000).

5 http://www.armymuseums.org.uk/, accessed on 20 June 2014.

6 I am grateful to Mark Smith, Curator, Royal Artillery Museum for this information (email 8 May 2014).

7 It must be is acknowledged that looting by soldiers was commonplace during wars at this time, as this was before Hague Conventions of 1899 and 1907.

8 National Army Museum, April 2013.

9 Visited in May 2011.

10 Guide to Royal Engineers Museum, n.d: 1

11 Personal communication, James Scott, 16 June 2014.

12 Gift. General Sir Richard Harrison G.C.B.

13 Gift. Miss S.E.R. Gordon.

14 Gift. Dame Kathleen Courtney DBE.

15 On the front of the leaflet is a photograph of Amitayas in the 'Chinese pagoda'.

16 Gift: Lieutenant Colonel E V Thompson.

17 Gift: Lady Harrison.

18 There are other Chinese objects, not necessarily associated with the 'Summer Palace' - a priming horn picked up at the storming of the Taku (sic.) Forts, a knife, headrest, tobacco pipe, razor, mallet, geomancer's compass, two fans, ceremonial pole-arm, matchlock musket, double swords and an imperial jacket.

19 Gordon, for example, was 'held to be an ideal of Victorian Christian morality and heroism' (Jones 1996: 153).

20 As Gale noted, 'It would be greatly to the advantage of the Corps and the Service at large if a proper building existed...for the reception of relics and objects illustrative of the lives of great soldiers...' (1894, unpaginated - in Jones 1996: 153).

21 Visited in July 2011.

22 Main text panel.

23 These are probably not from the Yuanmingyuan, though the exact provenance is not given.

24 Visited in June 2011.

25 http://www.thewardrobe.org.uk/museum/museum-history, accessed 20 June 2014. 
26 The museum has other material from the Yuanmingyuan in store. In particular, a pair of sleeves embroidered in dark blue, thought to once be the property of the Empress of China, classified under 'Miscellaneous clothing'.

27 Visit November 2011.

28 What was later to be known as the $44^{\text {th }}$ Regiment of Foot, was one of seven infantry regiments raised during the War of the Austrian Succession in 1741. The Regiment was amalgamated in 1958 and disbanded in 1992.

Personal communication, lan Hook, 24 November 2011.

He died in Bombay on 23 January 1865 aged 27 . He had already served in the Crimea (personal communication, lan Hook, 13 May 2010).

Personal communication, 24 November 2011. Ian Hook, personal communication, 22 May 2014. personal railway carriage of the dowager Empress of China during the Boxer Rebellion in Beijing in 1900. However, it is not known how they came into the possession of the Buffs, as the regiment did not take part in the Boxer Rebellion.

40 The 'Bv' might mean Brevet. I am grateful to Craig Bowen, Museums and Galleries Development Manager, The Beaney House of Art and Knowledge (Personal communication, 2 June 2014).

41 There is an 'Ornamental Screen', taken from the Yuanmingyuan in 1860, made of brass, glass, wood and velvet, collected by Sgn S Currie, The Buffs.

42 Text panel.

43 There are other military museums which hold Yuanmingyuan material, and unfortunately there is not enough space to discuss them in any detail in this paper. For example, the Royal Hampshire Regiment Museum in Winchester has two silver jars, presented to the 67th Regiment by Major D S Miller, Captain W H B Kingsley and Major F.W.Jebb. The museum also has a 'five clawed Imperial Dragon embroidery taken...by Colonel Bell Kingsley CB'. The Queen's Royal Surrey Regiment Museum, Clandon Park, Guildford has a vase and a 'Joss Head' (lan Chatfield, Personal communication, 2 March 2010). On display at Caernarfon Castle is a cloisonné jar from the Yuanmingyuan and a bronze Buddhist deity figure, taken by a Royal Welsh Fusilier during the Boxer Rebellion. There are a range of other looted objects from China (not necessarily from the Yuanmingyuan) in military museums. For example, a screen from the Temple of Heaven taken in 1860 at the Royal Scots Regimental Museum in Edinburgh Castle (My thanks to Desmond Thomas, Curator, Museum of the Royal Regiment of Scotland for supplying information on this); 
the National Army Museum has a painting of a Buddha taken by Garnet Wolseley from the Lama temple in Beijing in 1860, and a tiger headdress of a Manchu soldier from the Boxer Rebellion in 1900-1901 acquired by Col. Francis Garden Poole (Visited September 2013. My thanks to Alastair Massie, Head of Academic Access, National Army Museum for showing these to me). The Royal Artillery Museum has a cross bow, bamboo shield decorated with a painting of the face of a tiger and guns (my thanks to Mark Smith, Curator, Royal Artillery Museum).

\section{References}

Ames, M. (1992) Cannibal tours and glass boxes: the anthropology of museums, Vancouver: UBC Press.

Appadurai, A. (1986) 'Introduction: commodities and the politics of value', in Arjun Appadurai (ed) The social life of things: commodities in cultural perspective, 3-63, Cambridge: Cambridge University Press.

Atkinson (1950) Regimental History - The Royal Hampshire Regiment, Vol 1 to 1914, Glasgow: the University Press.

Chiu, C.B. (2000) Yuanming Yuan: Le Jardin de la Clarté parfaite, Besançon.

Classen, C. and Howes, D. (2006) 'The museum as sensescape: Western sensibilities and indigenous artifacts' in Edwards, Gosden and Philips (eds) Sensible objects: colonialism, museums and material culture, 199-222, Oxford and New York: Berg.

Clifford, J. (1997) 'Museums as contact zones', in Routes: travel and translation in the late twentieth century, 188-219, Cambridge, Massachusetts and London: Harvard University Press.

Dickinson, G. and Wrigglesworth, L. (2000) Imperial Wardrobe, Toronto: Ten Speed Press.

Errington, S. (1994) 'What became authentic primitive art?', Cultural Anthropology, 9(2) 201-226.

Henare, A. (2005) Museums, anthropology and imperial exchange, Cambridge: Cambridge University Press.

Hevia, J. (1994) 'Loot's fate: the economy of plunder and the moral life of objects from the Summer Palace of the Emperor of China', History and Anthropology, 6(4) 319-345.

Hevia, J. (1999) 'Looting Beijing: 1860, 1900', in Lydia He Liu (ed) Tokens of Exchange, Durham and Hong Kong: Duke University Press.

Hevia, J. (2003) English Lessons: The Pedagogy of Imperialism in Nineteenth-Century China, Durham and Hong Kong: Duke University Press.

Hill, K. (2005) Culture and class in English public museums, 1850-1914, Aldershot: Ashgate.

Hill, K. (2012a) 'Collecting on Campaign: British soldiers in China during the Opium Wars', Journal of the History of Collections, 25(2) 1-26.

Hill, K. (2012b) 'Chinese Ceramics in United Kingdom Military Museums', The Oriental Ceramic Society Newsletter, 20, May, 11-14. 
Hooper-Greenhill, E. (2000) Museums and the interpretation of visual culture, London and New York: Routledge.

Jones, S. (1996) 'Making Histories of Wars' in Gaynor Kavanagh (ed) Making Histories in Museums, 153-163, Leicester: Leicester University Press.

Jordanova, L. (1989) 'Objects of Knowledge' in Peter Vergo (ed) The new museology, 2439, London: Reaktion Books.

Kopytoff, I. (1986) 'The cultural biography of things: commoditisation as process', in Arjun Appadurai (ed) The social life of things: commodities in cultural perspective, 64-91, Cambridge: Cambridge University Press.

Macartney, J. (2009) 'China in worldwide treasure hunt for artefacts looted from Yuan Ming Yuan Palace', The Times, 20 October.

McCarthy, C. (2007) Exhibiting Maori: a history of colonial cultures of display, Oxford and New York, Berg.

McIntyre, M. (2007) The Wiltshire Regiment, 1756-1914, Stroud: Tempus.

Norman, C. B. (1911, reprinted 1971) Battle Honours of the British Army: from Tangier 1662, to the commencement of the reign of King Edward VII, London: John Murray.

Peers, L. and Brown, A. (eds) (2003) Museums and source communities: a Routledge reader, London and New York: Routledge.

Price, S. (1991) Primitive art in civilized places, Chicago: University of Chicago Press.

Ringmar, E. (2013) Liberal Barbarism: The European Destruction of the Palace of the Emperor of China, New York: Palgrave Macmillan.

Simpson, M. (1996) Making Representations: Museums in the Post-colonial Era, London and New: Routledge.

Steiner, C. (1994) African art in transit, Cambridge: Cambridge University Press.

The AMOT Guide to Military Museums in the UK, 2010/11 edition: Army Museums Ogilby Trust.

Thomas, G. (2008) 'The Looting of Yuanming and the Translation of Chinese Art in Europe', Nineteenth-Century art worldwide: a journal of nineteenth-century visual culture, 7 (2). http://www.19thc-artworldwide.org/index.php/autumn08/93-the-looting-ofyuanming-and-the-translation-of-chinese-art-in-europe

Thomas, N. (1991) Entangled objects: exchange, material culture and colonialism in the Pacific, Cambridge, Massachusets and London: Harvard University Press.

Tythacott, L. (2010) 'The Politics of Representation in Museums', in Marcia Bates (ed) Encyclopedia of Library and Information Sciences, 4230-4241, Third Edition, 1: 1, CRC Press, Taylor \& Francis Group: London.

Wong, Y.T. (2001) A Paradise Lost: The Imperial Garden Yuanming Yuan, University of Hawai'i Press.

Wolseley, G. (1862) Narrative of the War with China in 1860, Longman, Green, Longman and Roberts. 


\section{Guidebooks and museum leaflets:}

The Museum of The Royal Welch Fusiliers, Caernarfon Castle

Guide to Royal Engineers Museum

Beaney Institute Guidebook, 2012

Essex Regiment Museum leaflet

The Rifles (Berkshire and Wiltshire) Museum leaflet

*Louise Tythacott is Senior Lecturer in Curating and Museology of Asian Art at the School of Oriental and African Studies, University of London. She was previously Lecturer in Museology at the University of Manchester. She has worked in the museum field for over a decade, and has published widely on the relationships between museums, anthropology and non-Western art. Her books include Surrealism and the Exotic (Routledge, 2003), The Lives of Chinese Objects: Buddhism, Imperialism and Display (Berghahn, 2011) and Museums and Restitution: New Practices, New Approaches (eds. Ashgate, 2014).

Address:

Brunei Gallery, School of Oriental and African Studies, University of London Thornhaugh Street, Russell Square, London WC1H OXG

Email: It15@soas.ac.uk

Tel: 02078984159 